\title{
Variability in Groundnut Genotypes for Tolerance to Drought
}

\author{
S.B.Thakur ${ }^{1}$, S.K. Ghimire ${ }^{1}$, S.M. Shrestha ${ }^{1}$, N. K. Chaudhary ${ }^{1}$ and B. Mishra ${ }^{2}$ \\ ${ }^{1}$ Institute of Agriculture and Animal Science, Rampur, Chitwan \\ ${ }^{2}$ Nepal Agriculture Research Council, Khumaltar, Lalitpur \\ e-mail: sbthakur500@rediffmail.com
}

\begin{abstract}
Groundnut (Arachis hypogaea L.) is one of the world's most important legumes, both in subsistence and commercial agriculture in arid and semi-arid regions of the world. Global warming, an increasing threat, is expected to increase the water scarcity in the environment, affecting plant growth and metabolism. Groundnut yield in rain-fed areas has been limited by drought stress because pod yield and other growth parameters have been severely affected. Twenty five groundnut genotypes including four local checks (B-4, Rajashri, Baidehi and Jayanti) were composed and an experiment was conducted during 2010 and 2011 at the National Oilseed Research Program (NORP), Nawalpur, Sarlahi, Nepal. The experiment was conducted in a randomized complete block design in three replications. The objective of the study was to determine the genetic variability in different groundnut genotypes to drought tolerance. The analysis of variance indicated highly significant differences for most of plant the characters. Remarkable levels of variability have existed among the groundnut varieties that are essential in groundnut improvement. The genotypes ICGV-99171, ICGV-98089, ICGV-97100, Baidehi, ICGV-00440 and B-4 were observed better for drought tolerance with high pod yield. It is suggested that these genotypes could be grown under regions of limited rainfall and may be used as parents in breeding programmes for developing drought tolerant groundnut cultivars.
\end{abstract}

Key words: groundnut, drought tolerance, root shoot ratio, SLA, SCMR

\section{Introduction}

Groundnut (Arachis hypogaea L.) is an important legume crop both in subsistence and commercial agriculture in arid and semi-arid regions of the world (Izge et al. 2005). Groundnut yield in rain-fed areas has been limited by drought stress because the pod yield and other growth parameters have been severely affected (Pimratch et al. 2008, Nautiyal et al. 2002, Reddy et al. 2003, Nigam et al. 2005). Yield losses have been estimated to be $56-85 \%$ (Nageswara Rao et al. 1989), depending on crop growth stage when it was exposed to drought (Reddy et al. 2003), drought intensity and drought duration (Nautiyal et al. 2002, Nigam et al. 2005). Even in irrigated areas, groundnut is frequently exposed to drought because water supply is not sufficient. Frequent occurrence of drought is one of the limiting factors adversely affecting groundnut productivity, especially in rain fed areas.
Soil water deficits in the pegging and root zone decreases pod and seed growth rates by approximately $30 \%$ and decreases weight per seed from 563 to 428 mg. (Sexton et al. 1997). However, a large reduction in pod yield, and the reduction percentage also varies among peanut cultivars (Haris et al. 1988, Nageswara Rao et al. 1998).

The varieties should be able to provide higher yield under drought. Genetic variability for drought resistance has been reported in groundnut (Upadhyaya 2005, Songsri et al. 2009). However, breeding for drought resistance based on pod yield is lacking behind due to significant genotype and environment interactions (Wright et al. 1996).

In Nepal, groundnut is used as good quality cooking oil/vegetable ghee, confectionery and snacks and 
Nepal Journal of Science and Technology Vol. 14, No. 1 (2013) 41-50

generally grown in upland during monsoon season in 15000 ha merely on rain fed condition on river basin. Summer rainfall in southern Nepal has historically been very erratic, and long-term records suggest that while the average annual rainfall has remained relatively stable, rainfall during the peanut growing season has declined over the past decade. Four varieties of groundnut B-4, Janak, Jyoti and Jayanti have been released for general cultivation. Their successful production has been drastically affected by a number of problems such as the erratic rainfall as well as long time water stress in mid season (NORP/ NARC 2008).

Tailoring groundnut varieties with tolerance to drought and efficient in water use offers the best long term and cost effective solution to encounter the uncertainty of monsoon and shrinking availability of irrigation water in country. The use of droughtresistant varieties is an important strategy to combat the drought problem. Rapid progress in drought resistance breeding has been achieved based on characters like harvest index (HI), water use efficiency (WUE), specific leaf area (SLA) and SPAD chlorophyll meter reading (SCMR) (Nigam et al. 2005). The SLA and SCMR have been found to be highly correlated with WUE (Nageswara Rao et al. 2001, Sheshshayee et al. 2005) have been used as surrogate traits for WUE (Nigam et al. 2005, Lal et al. 2006, Sheshshayee et al. 2006, Arunyanark et al. 2008, Jongrungklang et al. 2008, Pimratch et al. 2008). Root systems also play a crucial role in determining shoot water status and therefore effective water uptake is an important determinant of drought resistance (Kashiwagi et al. 2006). Larger root systems and deep growth of root systems into lower soil profile can take up more water to support plant growth and yield (Ludlow \& Muchow 1990, Turner et al. 2001). Genetic variations for root characters have been found among groundnut genotypes (Ketring 1984).

The progress in breeding for drought resistance in peanut based on pod yield has been slow because of high genetic and environment interactions (Wright et al. 1996). The use of surrogate traits related to drought resistance has been suggested by many authors (Nageswara Rao et al. 2001, Nigam et al. 2005) as the inheritance of these characters must be simpler than pod yield. The information on the heritability and the relationships among the characters is important for plant breeders to formulate appropriate breeding strategies to achieve breeding goals. The aims of this study were to understand whether heritability estimates for characters under investigation were sufficient for further improvement of these characters and to explore whether physiological characters and other drought related characters could be used as surrogate traits for pod yield under drought condition.

The objective of the study was to determine the genetic variability in different groundnut genotypes to drought tolerance and its component traits so that it would be possible to identify the trait based drought tolerance genotypes for drought prone groundnut area and future groundnut improvement programme.

\section{Methodology}

The experiment was conducted at the experimental farm of the National Oilseed Research Program (NORP), Nawalpur, Sarlahi district, Nepal during rainy season in year 2010 and 2011. The area lies in the central Tarai with high potential for groundnut crop. The area lies between $85^{\circ} 35^{\prime}$ '52" east longitude and $27^{\circ} 03^{\prime}$ 86" north latitude. Average altitude of the district is 144 masl. Average maximum annual temperature ranged from 38 to $40^{\circ} \mathrm{C}$ and the minimum temperature ranged from 4 to $5^{\circ} \mathrm{C}$. Average annual rainfall was about 1200 to 1500 $\mathrm{mm}$. Soil of the experimental plot was sandy loam in texture with $\mathrm{pH}$ of 5.5 in the area. The climate was subtropical in average. It was dry with moderate temperature during vegetative and flowering stage and low rain at flowering stage with low temperature at late flowering and maturity stage of the crop. Twenty five genotypes included from NORP and ICRISAT including local check varieties (B-4, Rajashri, Baidehi and Jayanti) were used to study the different genetic variability parameters. The tested genotypes were confectionary type, tolerant to drought lines developed from ICRISAT including some of the recommended early and late varieties of Nepal. The experimental plots were prepared properly and were fertilized@ 20:40:20 Kg NPK ha-1 basally.

The experiment was laid out in a randomized complete block design (RCBD) in three replications (Fig 3). The plot size was $5.0 \mathrm{X} 1.2 \mathrm{~m}^{2}$ with space of $25 \mathrm{~cm}$. The distance between rows and plants was 30 and $15 \mathrm{~cm}$ respectively. On the other hand plot to plot and replication to replication distance was 0.5 and $1.0 \mathrm{~m}$ respectively. Seeds of genetic materials were sown on $1^{\text {st }}$ week of July, in 2010 and $2^{\text {nd }}$ week of July in 2011. 
Seeds were sown in furrow at the depth of $4 \mathrm{~cm}$ approximately. Two weeding were done at 15 and 28days after seeding. No irrigation was applied during total period of the experiment. The half part of each plot in every replication was covered with the 300 gauze plastic tunnel of bamboo stick to restrict the rain water completely at 28 to 75 days after seeding (DAS) called as water stress condition. After 80 DAS, plastic tunnel was uncovered to let rain water. The remaining half part of each plot was left to let rain called as normal condition.

SPAD SCMR and SLA were recorded at 8.00-9.00 a $\mathrm{m}$ at 70 days after sowing. The second to third leaves from the top of the main stem of each plant was detached and kept in plastic bags in an ice box. The leaf samples were soon transported to a laboratory and fresh weight was recorded. SCMR was measured immediately by a Minolta handheld portable SCMR meter (SPAD- 502 Minolta, Tokyo, Japan), using four leaflets per sample. In recording the SCMR, care was taken to ensure that the SPAD meter sensor fully covered the leaf lamina and the interference from veins and midribs could be avoided. The same samples were further measured for leaf area, using a leaf area meter (LI3100C Area meter, LI COR Inc., USA). The SLA was calculated using the following equation (Nageswara Rao et al. 2001):

$$
\text { Specific leaf area }(\mathrm{SLA})=\text { Weight of the leaves }
$$

The length of the root from surface to root tips and length of the shoot were measured. Then it was calculated in ratio as formula given bellow:

$$
\begin{gathered}
\text { Length of the root } \\
\text { Roots=------ } \\
\text { Length of the shoot }
\end{gathered}
$$

Drought scoring was recorded by following the scoring system: Normal leaf-1, Some of the plant leaves turn back2 , Total plant leaves turn back-3, Whole leaves of the plot turn back-4 and Total plant destroyed-5.

The shelling percentage was calculated by using the following formula:

$$
\begin{aligned}
\text { Shelling \% } \%= & \text { Net kernel weight (pod weight-shell weight) } \\
\text { Total pod weight } & 100
\end{aligned}
$$

The 100 kernel weights were calculated by randomly selected 100 kernels from each plot.

The data were subjected to analysis of variance (ANOVA) using SPPSS software and the means were compared using Duncan's Multiple Range Test (DMRT) at 5\% level of probability according to Duncan (1955). The coefficient of variability were calculated by a formula suggested by Burton (1952).

\section{Results and Discussion}

Characters taken for the study are major indicators of pod yield and kernel yield of groundnut. The ANOVA indicating the sources of variation and mean squares for the yield and yield component traits among the groundnut genotypes are presented in Table 1 . The result indicated highly significant variation among the genotypes for the traits; pod per plant, shelling\%, haulm yield, root and shoot ratio, SLA, SCMR and drought score, and significant difference was observed for 100 kernel weight and pod yield ha $^{-1}$. These results indicated that the genotypes varied for the traits. The findings are similar to some of the early workers Branch \& Kvien 1992, Hamidou et al. 2012).

Table 1. Analysis of variance (ANOVA) showing mean squares for yield components and drought related traits in groundnut genotypes during water stress conditions.

\begin{tabular}{l|c|c|c|c}
\hline \multicolumn{1}{c|}{ Source of variation } & $\begin{array}{c}\text { Replication } \\
\mathbf{d f}=\mathbf{2}\end{array}$ & $\begin{array}{c}\text { Treatments } \\
\mathbf{d f = 2 4}\end{array}$ & $\begin{array}{c}\text { Error } \\
\mathbf{d f = 4 8}\end{array}$ & F value \\
\hline Pod per plant (No) & 376.17 & $45.11^{* *}$ & 36.06 & 1.37 \\
100 kernel wt.(g) & 57.95 & $162.78^{*}$ & 48.43 & 5.17 \\
Shelling \% & 42.05 & $103.45^{* *}$ & 59.22 & 0.66 \\
Pod yield (kg/ha) & 149867.50 & $160014.77^{*}$ & 183820.40 & 1.11 \\
Haulm yield (t/ha) & 18.00 & $97.00^{* *}$ & 23.47 & 0.07 \\
Root shoot ratio & 0.11 & $0.024^{* *}$ & 0.020 & 1.18 \\
SLA & 1253.70 & $1855.84^{* *}$ & 903.83 & 1.82 \\
SCMR & 57.91 & $26.03^{* *}$ & 20.73 & 1.03 \\
Drought score & 98361655.32 & $14259898.88^{* *}$ & 9167924.50 & 1.43 \\
\hline
\end{tabular}

\footnotetext{
* and $* *=$ Significant at $5 \%$ probability level and highly significant at $1 \%$ probability level respectively.
} 
Nepal Journal of Science and Technology Vol. 14, No. 1 (2013) 41-50

Table 2 (a). Performance of different traits under water stress and normal rain fed condition during 20102011 in 25 groundnut genotypes

\begin{tabular}{|c|c|c|c|c|c|c|c|c|}
\hline \multirow[b]{2}{*}{ Genotype } & \multicolumn{2}{|c|}{ Pod/plant(no) } & \multicolumn{2}{|c|}{100 kernel weight(g) } & \multicolumn{2}{|c|}{ Shelling (\%) } & \multicolumn{2}{|c|}{$\begin{array}{c}\text { Pod yield } \\
(\mathrm{kg} / \mathrm{ha})\end{array}$} \\
\hline & $\begin{array}{l}\text { Water } \\
\text { stress }\end{array}$ & Normal & $\begin{array}{l}\text { Water } \\
\text { stress }\end{array}$ & Normal & $\begin{array}{l}\text { Water } \\
\text { stress }\end{array}$ & Normal & $\begin{array}{l}\text { Water } \\
\text { stress }\end{array}$ & Normal \\
\hline $\begin{array}{l}\text { ICGV- } \\
99171\end{array}$ & 18.9 & 23.8 & 38.9 & 40.2 & 54.9 & 72.2 & 1293.9 & 2614.4 \\
\hline $\begin{array}{l}\text { ICGV- } \\
97100\end{array}$ & 18.8 & 21.8 & 31.1 & 35.9 & 62.5 & 77.6 & 1030.0 & 2681.1 \\
\hline Rajashri & 15.6 & 20.8 & 37.5 & 41.5 & 65.8 & 68.0 & 995.0 & 2200.5 \\
\hline $\begin{array}{l}\text { ICGV- } \\
98088\end{array}$ & 18.9 & 22.7 & 35.8 & 39.6 & 64.4 & 66.9 & 877.8 & 1669.4 \\
\hline B-4 & 14.5 & 16.7 & 35.1 & 39.2 & 69.4 & 73.9 & 610.0 & 1610.5 \\
\hline $\begin{array}{l}\text { ICGV- } \\
97098\end{array}$ & 15.8 & 23.6 & 35.0 & 33.7 & 55.2 & 77.2 & 718.3 & 1572.2 \\
\hline $\begin{array}{l}\text { ICGV- } \\
97093\end{array}$ & 15.0 & 17.6 & 32.7 & 40.9 & 77.2 & 65.0 & 521.7 & 1696.1 \\
\hline $\begin{array}{l}\text { ICGV- } \\
980100\end{array}$ & 16.8 & 19.3 & 33.9 & 37.1 & 61.3 & 66.5 & 553.3 & 1930.6 \\
\hline $\begin{array}{l}\text { ICGV- } \\
91104\end{array}$ & 15.2 & 18.3 & 46.9 & 58.1 & 60.2 & 69.7 & 786.7 & 2172.8 \\
\hline $\begin{array}{l}\text { ICGV- } \\
86124\end{array}$ & 15.4 & 17.1 & 42.5 & 44.2 & 71.2 & 70.6 & 1032.2 & 1899.4 \\
\hline $\begin{array}{l}\text { ICGV- } \\
91058\end{array}$ & 17.7 & 16.5 & 38.0 & 51.4 & 70.7 & 71.6 & 894.4 & 2364.4 \\
\hline $\begin{array}{l}\text { ICGV- } \\
91114\end{array}$ & 16.1 & 21.9 & 40.4 & 38.6 & 70.3 & 74.4 & 864.4 & 2010.0 \\
\hline Jyanti & 20.8 & 20.1 & 34.8 & 38.7 & 67.4 & 73.0 & 867.2 & 2261.7 \\
\hline $\begin{array}{l}\text { ICGV- } \\
98089\end{array}$ & 18.4 & 22.8 & 34.3 & 36.8 & 63.4 & 70.9 & 1023.3 & 2106.1 \\
\hline $\begin{array}{l}\text { ICGV- } \\
92173\end{array}$ & 22.3 & 25.4 & 33.7 & 36.1 & 67.2 & 66.7 & 756.1 & 2603.3 \\
\hline $\begin{array}{l}\text { ICGV- } \\
88473\end{array}$ & 18.3 & 18.9 & 43.1 & 56.4 & 60.8 & 73.0 & 968.3 & 2311.1 \\
\hline $\begin{array}{l}\text { ICGV- } \\
97087\end{array}$ & 19.6 & 23.7 & 29.7 & 39.1 & 63.7 & 64.0 & 670.0 & 1278.3 \\
\hline $\begin{array}{l}\text { ICGV- } \\
86339\end{array}$ & 16.4 & 19.4 & 34.3 & 36.0 & 71.1 & 76.6 & 1031.7 & 1979.4 \\
\hline Baidehi & 14.9 & 18.2 & 39.1 & 38.6 & 77.2 & 75.9 & 1050.6 & 2241.1 \\
\hline $\begin{array}{l}\text { ICGV- } \\
91074\end{array}$ & 14.5 & 20.7 & 43.4 & 54.2 & 63.4 & 68.8 & 896.1 & 2498.9 \\
\hline $\begin{array}{l}\text { ICGV- } \\
97243\end{array}$ & 15.9 & 21.0 & 27.6 & 35.9 & 68.9 & 69.2 & 499.4 & 1320.0 \\
\hline $\begin{array}{l}\text { ICGV- } \\
00350\end{array}$ & 14.7 & 23.9 & 30.8 & 35.3 & 65.5 & 72.7 & 1076.1 & 2630.6 \\
\hline $\begin{array}{c}\text { ICGV- } \\
95017\end{array}$ & 23.1 & 28.2 & 31.0 & 33.0 & 68.9 & 69.1 & 640.0 & 1780.6 \\
\hline $\begin{array}{l}\text { ICGV- } \\
95005\end{array}$ & 21.4 & 29.2 & 29.1 & 31.9 & 63.7 & 73.0 & 443.3 & 1601.1 \\
\hline $\begin{array}{l}\text { ICGV- } \\
00440\end{array}$ & 15.8 & 21.2 & 47.9 & 60.2 & 61.7 & 72.3 & 952.8 & 2605.5 \\
\hline$\ddot{x}$ & 17.38 & 21.25 & 36.27 & 41.31 & 65.39 & 71.14 & 842.41 & 987.86 \\
\hline $\mathrm{CV} \%$ & 31.77 & 32.7 & 18.83 & 15.96 & 11.75 & 11.0 & 38.03 & 30.02 \\
\hline
\end{tabular}


S.B.Thakur \& S.K. Ghimire/Variability in Groundnut Genotypes

The results are in agreement with the results obtained by Nath and Alam (2002), who found highly significant variation among the genotypes for the characters, pods plant ${ }^{-1}, 100$ seed weight, shelling $\%$ and pod yield plot $^{-1}$. The similar results were found by Upadhya et al. (2011) for SCMR and SLA and Thakur et al. (2011) for root and shoot ratio, SLA and SCMR. Vadez et al. (2011) also found significant difference for the root and shoot ratio.

Table 2 (b). Performance of different traits under water stress and normal rain fed condition during 20102011 in 25 groundnut genotypes

\begin{tabular}{|c|c|c|c|c|c|c|c|c|c|}
\hline \multirow{2}{*}{ Genotype } & \multicolumn{2}{|c|}{$\begin{array}{l}\text { Haulm wt } \\
\text { (t/ha) }\end{array}$} & \multicolumn{2}{|c|}{ Root shoot ratio } & \multicolumn{2}{|c|}{ SLA } & \multicolumn{2}{|c|}{ SCMR } & \multirow{2}{*}{$\begin{array}{c}\text { Drought } \\
\text { score } \\
(1-5 \\
\text { scale })\end{array}$} \\
\hline & $\begin{array}{l}\text { Water } \\
\text { stress }\end{array}$ & Normal & $\begin{array}{l}\text { Water } \\
\text { stress }\end{array}$ & Normal & $\begin{array}{l}\text { Water } \\
\text { stress }\end{array}$ & Normal & $\begin{array}{l}\text { Water } \\
\text { stress }\end{array}$ & Normal & \\
\hline ICGV-99171 & 7.4 & 13.9 & 0.54 & 0.66 & 96.9 & 95.3 & 38.1 & 39.3 & 2.0 \\
\hline ICGV-97100 & 8.9 & 11.1 & 0.37 & 0.62 & 77.3 & 80.8 & 34.1 & 39.1 & 2.7 \\
\hline Rajashri & 12.7 & 13.0 & 0.46 & 0.58 & 94.8 & 81.3 & 35.2 & 43.0 & 2.0 \\
\hline ICGV-98088 & 12.9 & 11.3 & 0.38 & 0.53 & 139.6 & 152.7 & 38.0 & 40.1 & 2.3 \\
\hline B-4 & 11.7 & 15.3 & 0.42 & 0.59 & 89.5 & 90.1 & 36.7 & 39.7 & 2.3 \\
\hline ICGV-97098 & 11.6 & 9.5 & 0.41 & 0.54 & 105.5 & 111.9 & 37.7 & 37.1 & 3.0 \\
\hline ICGV-97093 & 9.6 & 13.3 & 0.38 & 0.56 & 132.2 & 122.5 & 33.1 & 37.7 & 2.3 \\
\hline ICGV-980100 & 9.2 & 11.9 & 0.54 & 0.64 & 111.2 & 97.5 & 40.3 & 40.8 & 2.3 \\
\hline ICGV-91104 & 13.1 & 16.7 & 0.33 & 0.51 & 122.7 & 115.6 & 35.3 & 35.9 & 2.0 \\
\hline ICGV-86124 & 7.9 & 9.9 & 0.37 & 0.51 & 125.1 & 111.6 & 36.3 & 37.6 & 2.3 \\
\hline ICGV-91058 & 13.4 & 14.9 & 0.42 & 0.49 & 125.9 & 132.0 & 33.8 & 36.4 & 1.7 \\
\hline ICGV-91114 & 9.7 & 12.1 & 0.40 & 0.48 & 140.7 & 133.4 & 35.2 & 32.3 & 2.7 \\
\hline Jyanti & 8.4 & 8.8 & 0.45 & 0.57 & 156.8 & 108.5 & 33.2 & 38.9 & 2.7 \\
\hline ICGV-98089 & 11.8 & 14.0 & 0.51 & 0.63 & 96.9 & 88.3 & 38.4 & 42.9 & 1.7 \\
\hline ICGV-92173 & 8.4 & 16.0 & 0.71 & 0.51 & 108.1 & 92.1 & 37.9 & 40.0 & 2.3 \\
\hline ICGV-88473 & 11.0 & 14.3 & 0.42 & 0.54 & 112.2 & 99.6 & 38.0 & 36.4 & 1.7 \\
\hline ICGV-97087 & 9.6 & 12.0 & 0.34 & 0.60 & 131.1 & 119.3 & 37.6 & 37.9 & 2.3 \\
\hline ICGV-86339 & 11.2 & 9.6 & 0.34 & 0.52 & 117.6 & 167.1 & 37.0 & 38.7 & 2.0 \\
\hline Baidehi & 6.4 & 10.5 & 0.56 & 0.58 & 141.2 & 137.2 & 36.6 & 37.3 & 2.3 \\
\hline ICGV-91074 & 9.0 & 14.7 & 0.60 & 0.52 & 118.0 & 117.6 & 34.6 & 39.3 & 2.0 \\
\hline ICGV-97243 & 10.0 & 12.7 & 0.40 & 0.45 & 131.9 & 138.3 & 35.2 & 37.8 & 2.0 \\
\hline ICGV-00350 & 12.7 & 11.5 & 0.42 & 0.49 & 125.3 & 127.8 & 33.6 & 36.9 & 2.3 \\
\hline ICGV-95017 & 9.0 & 9.9 & 0.43 & 0.66 & 157.6 & 131.8 & 38.0 & 41.1 & 2.3 \\
\hline ICGV-95005 & 11.3 & 10.8 & 0.38 & 0.53 & 113.9 & 134.6 & 36.4 & 39.6 & 2.7 \\
\hline ICGV-00440 & 8.6 & 13.4 & 0.55 & 0.65 & 114.4 & 98.5 & 41.5 & 39.5 & 2.0 \\
\hline$\ddot{X}$ & 10.2 & 12.4 & 0.433 & 0.56 & 120.46 & 115.4 & 36.47 & 38.62 & 2.2 \\
\hline CV\% & 32.46 & 24.3 & 32.47 & 27.9 & 25.39 & 26.68 & 12.37 & 11.0 & 22.0 \\
\hline
\end{tabular}

The genotypes, ICGV-00440, ICGV-91104, ICGV-91074 and ICGV-88473 recorded the highest 100 kernel weight of 47.9, 46.9, 43.4 and $43.1 \mathrm{~g}$ respectively, while the genotypes ICGV-97243, had the lowest 100 kernel
The mean performance values for the groundnut genotypes in all the characters studied in year 2010 and 2011 under water stress and normal conditions are presented in Table 2 (a \&b). The results indicated that ICGV-95017, ICGV-92173 and ICGV-95005 recorded highest pods per plant (23.1, 22.3 and 21.4), respectively in water stress condition. However, the lowest pods were observed in B-4, ICGV-91074, ICGV00350 and Baidehi with 14.5, 14.5, 14.7 and 14.9 respectively. ICGV-95005 and ICGV-92173 had also the highest pods per plant under normal condition. weight of $27.6 \mathrm{~g}$ under water stress condition. Genotypes ICGV-00440 and ICGV-91104 had the highest 100 kernel weight of 60.2 and $58 \mathrm{~g}$ under normal condition. The differences in variation in water stress 
and normal condition in 100 kernel weight could be due to the high phosphorelation, corboxilation and photosynthesis in normal or having water. Under water stress, pegging and seed set responses of various peanut cultivars varied substantially as reported by Haris et al. (1988), Nageswara Rao et al. (1998).

The results also showed that significant differences were observed among groundnut varieties in shelling \%. ICGV-97093, Baidehi and ICGV-86124 showed the highest shelling \% of $77.2,77.2$ and $71.2 \%$ respectively. The lowest shelling \% was observed in ICGV-99171(54.9\%) under water stress. The genotype ICGV-97100 and Baidehi had the highest shelling \% with 77.6 and $75.9 \%$ under normal condition. This is also due to similar reason of high water use efficiency and photosynthesis.

The highest haulm yield was produced by ICGV-91058 and ICGV-91104 with 13.4 and 13.1 t ha $^{-1}$ respectively. The lowest haulm weight of $6.4 \mathrm{mt} /$ ha was produced by Baidehi under water stress condition. Similarly, the highest haulm yield of 16.7, 16.1 and $15.3 \mathrm{t} \mathrm{ha}^{-1}$ was observed in ICGV-91104 and ICGV-92173 and B-4 respectively (Fig 1).

The highest pod yield per hectare was observed in genotypes ICGV-99171, ICGV-00350, Baidehi, ICGV00350, ICGV-86124 and ICGV-97100 with 1293.9, 1076.1, 1050.6, 1032.2 and $1030.0 \mathrm{~kg} \mathrm{ha}^{-1}$ respectively. The lowest pod yield per hectare was shown in genotypes ICGV-95005with 443.3kg/ha under water stress. Under normal condition the highest pod yield was observed in ICGV-97100 (2681.1), ICGV-00350 (2630.6) and ICGV99171(2614.4).

The drought tolerance parameter, root to shoot ratio was significantly different among the investigated genotypes. The highest root to shoot ratio was recorded in ICGV-92173 with 0.70 and followed by ICGV-91074 (0.59), Baidehi (0.55), ICGV-00440 (0.55), ICGV-99171 (0.54) and ICGV-980100 (0.53) in water stress. The lowest root to shoot ratio was observed in ICGV-91104 (0.33). However, the highest root shoot ratio was recorded in ICGV-99171 (0.66), ICGV-95017 (0.66) and ICGV-00440 (0.65) under normal condition. Similar finding was obtained by Thakur et. al. (2011) for ICGV-980100 with higher root shoot ratio. The genotype exhibiting deeper root has more capacity of water absorption from deeper layer of soil in water deficit situation.
The physiological parameter for drought tolerance of groundnut genotypes differed much in SLA value in water stress and normal condition. SLA was negatively correlated with water use efficiency in turn pod yield (Basu and Nautiyal 2004). The result indicated that the highest SLA was observed in ICGV-95017, Jyanti, Baidehi, ICGV-91114 and ICGV-98088 with 156.8, 141.2, 140.7 and 139.6 respectively. These genotypes were found having thinner leaves and low water use efficiency. However, the lowest level of SLA was observed in ICGV-97100, B-4, Rajshree, ICGV-98089 and ICGV-99171 with 77.3, 89.5, 94.80, 96.86 and 96.93 respectively in water stress. Similarly, the ICGV-97100, B-4, Rajshree, ICGV-98089 and ICGV-99171 genotypes showed lower SLA in normal condition, have advantage in drought condition. Rao and Wright (2006) also observed that low SLA and high SCMR and high harvest index have advantage under drought condition. Similarly, Basu and Nautyal (2004) conferred that low SLA types are capable of retaining more water in the leaves under water stress situation than high SLA genotypes.

On the other hand the SCMR value also differed among the genotypes studied. The highest SCMR value was recorded in ICGV-00440 (41.5), ICGV-980100 (40.3) and ICGV-98089 (38.4). These genotypes were more water efficient under water deficit situation due to more chlorophyll density. Painawadee et al. (2009) and Arunyanark et al. (2008 and 2009) reported that SCMR was positively closely related with chlorophyll density and it is an indicator of the photo-synthetically active light-transmittance characteristics of the leaf (Richardson et al. 2002).

The lowest SCMR was recorded in ICGV-97093with 33.1 under water stress. However, Rajashri, ICGV-98089 and ICGV-95017 recorded the highest SCMR of 43.0, 42.9 and 41.1 respectively under normal condition. This result is in agreement with finding of Rao and Wright (2006) indicating higher SCMR related to higher water use efficiency.

Based on physical observation of the drought score ICGV-97098, ICGV-97100, ICGV-91114, ICGV-95005 and Jyanti showed the highest level of incidence to drought with 3.0, 2.7, 2.7 and 2.7 respectively under water stress condition. However, the genotype ICGV-88473, ICGV98089, and ICGV-91058 showed highest level of 
tolerance to drought with 1.7 score to drought. These genotypes may be used as the parent material in breeding program for drought tolerance of groundnut.

ICGV-99171 was found having highest yield, higher shelling \% , highest level of root shoot ratio (0.54), lower SLA (96.9), highest level of SCMR (38.11) and low level of reaction to drought (2.0) under water stress. The genotype ICGV-98089 had high yielding; high root and shoot ratio (0.50) and SCMR (38.41), and the lowest drought score and lower SLA of 96.867 indicating the highest tolerance to drought. Among the recommended high yielding variety Baidehi showed the highest root shoot ratio ( 0.55), SLA of 141.22, moderate SCMR of 36.60 and comparatively low incidence to drought (2.3). The moderate yielding ICGV-00440 had high root shoot ratio (0.55) and SCMR (41.54) and moderate SLA (114.41) and low score to drought (2.0). However, ICGV-95017 showed low yield but moderate root shoot ratio, highest pod per plant (23.13), SLA of 157.65 and SCMR of 38.01 and with moderate level of drought tolerance. The variety ICGV980100 recorded low yield but high shelling\%.
However, it showed the highest root shoot ratio (0.53), SCMR of 40.33 and moderate SLA (111.22) and moderate score to drought (2.3).

ICGV-91114 showed the medium SLA, medium SCMR, medium root shoot ratio and low drought score with medium pod yield and haulm yield. This finding is in agreement with ICRISAT report (2012) that ICGV-91114 resists drought and disease, and has good fodder quality and high shelling turnover of $75 \%$. Similar result was observed by Upadhya et al. (2011) showing high SLA and SCMR genotype had highest yield. Basu and Nautiyal (2004) also recorded that low SLA and high SCMR genotype had high WUE exhibiting direct indication of drought tolerance.

The genotypes ICGV-99171, Baidehi, ICGV-98089, ICGV-00440, ICGV-980100 and ICGV-91114 are termed as drought tolerant genotypes, as drought tolerance has been defined as the ability of one genotype to be more productive with a given amount of soil moisture than another genotype (Quizenberry 1982).

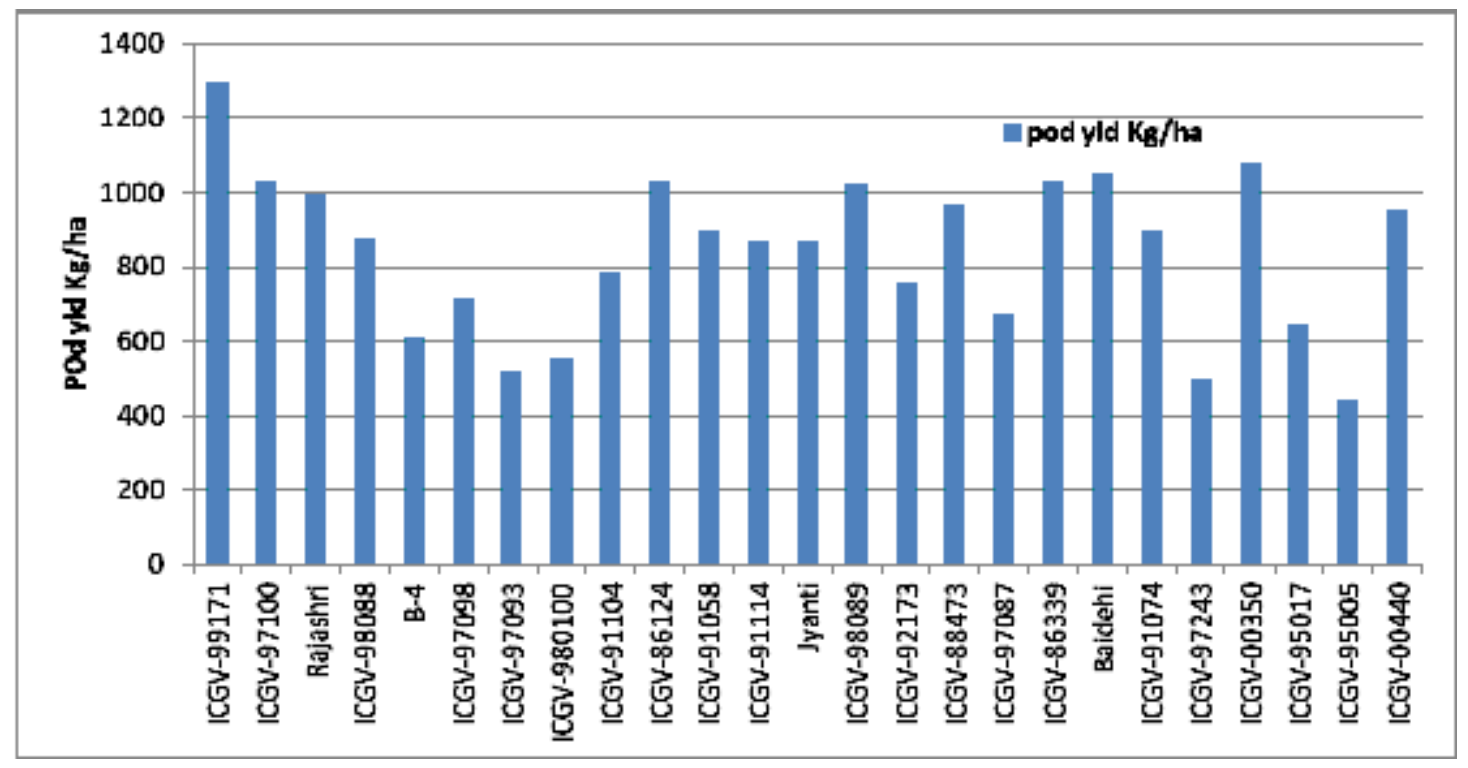

Fig. 1. Average pod yield $\left(\mathrm{kg} \mathrm{ha}^{-1}\right)$ of various groundnut genotypes under water stress condition during 2010 and 2011

Thus, the remarkable level of variability existing among the groundnut genotypes studied indicated a positive step for their improvement (Fig.2). The presence of genetic variability in crop plants have been described as essential in plant breeding by Falconer (1989) and Izege et al. (2005). Genetic variability encourages selection, because selection on its own does not create variability. 


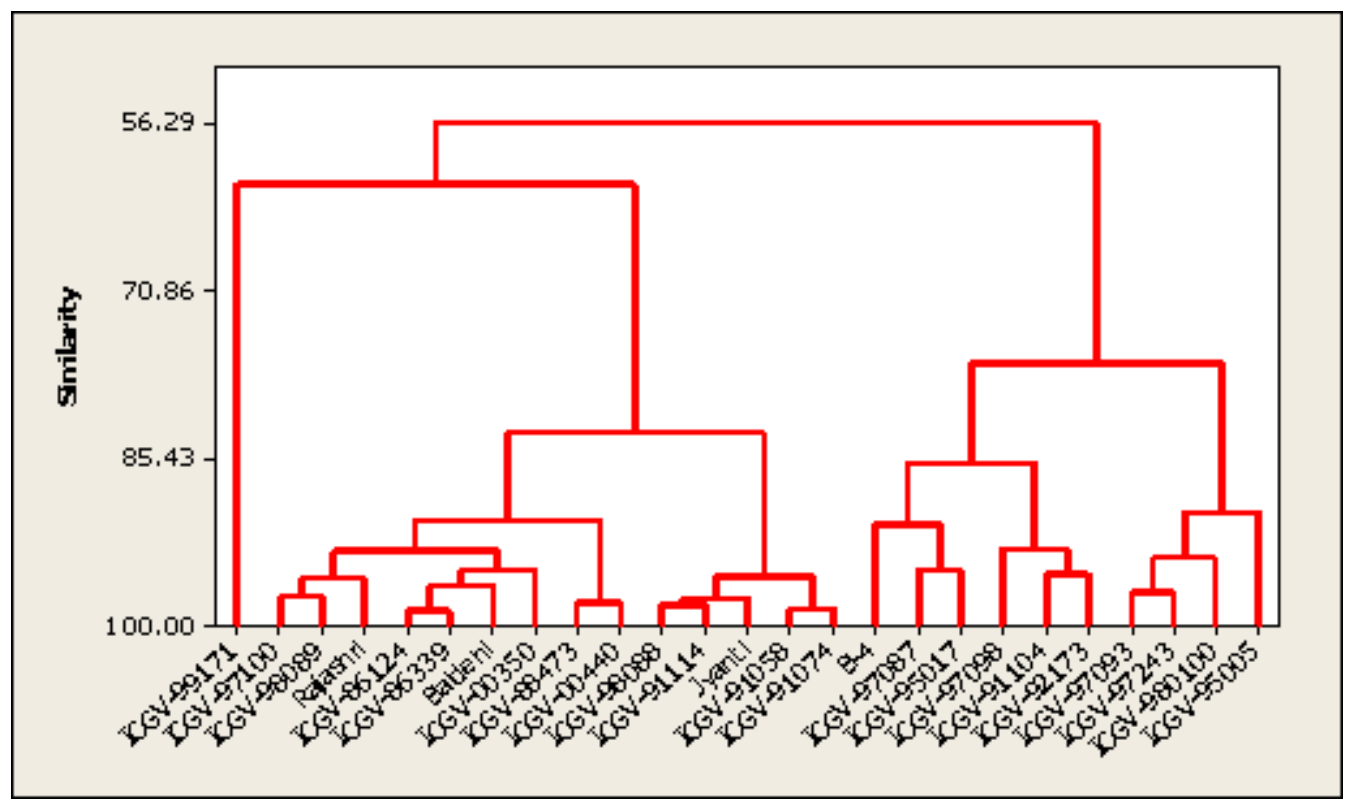

Fig. 2. Dendogram exhibiting the clusters of groundnut genotypes reaction to drought tolerance and yield component traits

Most of the indicators used in the study were significant among the genotypes. The results indicated that the genotypes ICGV-99171, ICGV-98089, ICGV97100, Baidehi, ICGV-00440, and B-4 showed tolerance to drought related traits and pod yield traits. Hence, it is suggested that these genotypes could be grown under regions of limited rainfall and adverse situation of climate change in future. These lines may be used as source of parents in breeding programmes for developing drought tolerant cultivars. This will be an advantage to semiarid groundnut farmers. Further study is required on drought resistance for groundnut improvement.

\section{Acknowledgements}

We are grateful to IAAS, Rampur, Chitwan and Department of Plant Breeding of IAAS, Rampur for all the academic support. We highly acknowledge the National Oilseed Research Program (NORP)/, NARC for providing genetic materials and research field. We sincerly acknowledge NARDF for providing us the research grant. Our sincere thanks go to all the people, to all who had assisted us in data collection, processing and academic advises.

\section{References}

Anonymous. 2012. An ICRISAT groundnut variety resists drought and diseases. Proceeding of ICRISAT, India.
Arunyanark, A., S. Jogloy, C. Akkasaeng, N. Vorasoot, T. Kesmala, R.C. Nageswara Rao, G.C. Wright and A. Patanothai. 2008. Chlorophyll stability is an indicator of drought tolerance in peanut. J. Agron.194: 113125.

Falconer, D. S. 1989. Introduction to quantitative genetics. 3rd ed. Longman Scientific and Technical, Essex, England. 389 pp.

Gregory, P.J. 2006. The functioning root system: Plant roots growth, activity and interaction with Soils. Blackwell Publishing Ltd., Oxford, UK.

Hamidou, F., P. Ratnakumar, O. Halilou, O. Mponda, T. Kapewa, E. Monyo, I. Faye, B.R. Ntare, S.N. Nigam, H.D. Upadhyaya and V. Vadez. 2012. Field Crops Research 126: 189-199.

Harris, D., R.B. Matthews, Nageswara Rao, R.C.and J.H. Williams, 1988. The Physiological basis for yield differences between four genotypes of groundnut (Arachis hypogaea L.) In Response To drought. Experimental Agriculture, 24 : 215-226.

Izge, A.U., M.A. Abubakar and C.A. Echekwu. 2005. Estimation of genetic and environmental variance components in pearl millet (Pennisetum glaucum L.) genotypes. Nig J. Appl. Exp. Biol. 6(1): 105-114.

Jongrungklang, N., B. Toomsan, N. Vorasoot, S. Jogloy, T. Kesmala and A. Patanothai. 2008. Identification of peanut genotypes with high water use efficiency under drought stress conditions from peanut germplasm of diverse origins. Asian J. Plant Sci. 7: 628-638.

Kashiwagi, J., L. Krishnamurthy, J.H. Crouch and R. Serraj. 2006. Variability of root length density and its contributions 
to seed yield in chickpea (Cicer arietinum L.) under terminal drought stress. Field Crops Res., 95: 171-181.

Ketring, D.L. 1984. Root diversity among peanut genotypes. Crop Sci. 24: 229-232.

Lal, C., K. Hariprasanna, A. L. Rathnakumar, H.K. Gor and B.M. Chikani. 2006. Gene action for surrogate traits of water-use efficiency and harvest index in peanut (Arachis hypogaea). Ann. Applied Biol., 148: 165-172.

Ludlow, M.M. and R.C. Muchow. 1990. A critical evaluation of traits for improving crop yield in water-limited environments. Adv. Agron. 43: 107-153.

Nageswara Rao, R.C., H.S. Talwar and G.C. Wright. 2001. Rapid assessment of specific leaf area and leaf nitrogen in peanut (Arachis hypogaea L.) using chlorophyll meter. $J$. Agron. 189: 175-182.

Nageswara Rao, R.C., J.H. Williams and M. Singh. 1989. Genotypic sensitivity to drought and yield potential of peanut. Agron. J. 81: 887-893.

Nageswara Rao, R.C., L.J. Reddy, V.K. Mehan, S.N. Nigam and D. McDonald. 1992. Drought research on groundnut at ICRISAT. In: Proceedings of the international work shop, groundnut-a global perspective, Nov. 25-29, ICRISAT Center, Andhra Pradesh, India,: pp. 455-455

Nageswara Rao, R.C. Williams, J.H., Sivakumar, M.V.K. and K.R.D. Wadia 1998. Effect of water deficit at different growth phases of peanut. Response to drought during pre-flowering phase Agron J. 80: 431-438.

Nautiyal, P.C., R.C. Nageswara Rao and Y.C. Joshi. 2002. Moisture-deficit-induced changes in leaf-water content, leaf carbon exchange rate and biomass production in groundnut cultivars differing in specific leaf area. Field Crops Res. 74: 67-79.

Nigam, S.N., S. Chandra, K. Rupa Sridevi, Manohar Bhukta and A.G.S. Reddy et al. 2005. Efficiency of physiological trait-based and empirical selection approaches for drought tolerance in groundnut. Ann. Applied Biol. 146: 433-439.

NORP. 2008. Annual report National Oilseed Research Program, Nawalpur/ NARC.

Painawadee, M., S. Jogloy, T. Kesmala, C. Akkasaeng and A. Patanothai .2009. Heritability and correlation of drought resistance traits and agronomic traits in peanut (Arachis hypogaea L.). Asian J. Plant Sci. 8: 325-334.

Pimratch, S., S. Jogloy, N. Vorasoot, B. Toomsan, A. Patanothai and C.C. Holbrook . 2008. Relationship between biomass production and nitrogen fixation under drought stress conditions in peanut genotypes with different levels of drought resistance. J. Agron. 194: 15-25.

Quizenberry, J.E. 1982. Breeding plant for less favourable environments, Eds. (Christiansen, M.N. and Lewis C.R.). John Wiley and Sons, New York, 193-212.

Rao, N. and Wright. 2003. In :International Arachis News letter, 26.
Reddy, T.Y., V.R. Reddy and V. Anbumozhi. 2003. Physiological responses of groundnut (Arachis hypogea L.) to drought stress and its amelioration: A critical review. Plant Growth Regulators 41: 75-88.

Sexton, P.J., J.M Benett and K.J. Boote. 1997. The effect of dry use efficiency and carbon isotope discrimination in peanut under pegging Zone Soil on pod formation. Peanut Science 24,pp. 19-24.

Richardson, A.D., S.P. Duigan and G.P. Berlyn. 2002. An evaluation of noninvasive methods to estimate foliar chlorophyll content. New Phytologist, 153: 185-194.

Sheshshayee, M.S., H. Bindumadhava, N.R. Rachaputi, T.G. Prasad, M. Udayakumar, G.C. Wright and S.N. Nigam. 2005. Leaf chlorophyll concentration relates to transpiration efficiency in peanut. Ann. Applied Biol. 148: 7-15.

Songsri, P., S. Jogloy, C.C. Holbrook, T. Kesmala, N. Vorasoot, C. Akkasaeng and A. Patanothai. 2009. Association of root, specific leaf area and SPAD chlorophyll meter reading to water use efficiency of peanut under different available soil water. Agric. Water Manage. 96: 790-798.

Songsri, P., S. Jogloy, T. Kesmala, N. Vorasoot, C. Akkasaeng, A. Patanothai and C.C. Holbrook. 2008. Heritability of drought resistance traits and correlation of drought resistance and agronomic traits in peanut. Crop Sci. 48: 2245-2253.

Thakur, SB., S.K. Ghimire, M.P. Pandey, S.M. Shrestha and B. Mishra. 2011. Genetic variabilty and genetic advance of podyield component traits of groundnut (Arachis hypogaea L.). J. Inst. Agric. Anim. Sci. 32: $133-141$.

Turner, N.C. 1986. Crop water deficits: a decade of progress. Advances in Agronomy 39, 1-15.

Upadhyaya, H.D. 2005. Variability for drought resistance related traits in the mini core collection of peanut Crop Sci. 45: 1432-1440.

Upadhyaya. H. D., S. Sharma, .S. Singh and M. Singh. 2011. Inheritance of drought resistance related traits in two crosses of groundnut (Arachis hypogaea L.), italyEuphytica , 177:55-66.

Vadez V., J.d S. Rao, P. Bhatnagar-Mathur and K. K. Sharma. 2011. DREB1A promotes root development in deep soil layers and increases water extraction under water stress in groundnut. In: Plant Biology. International Crops Research Institute for the SemiArid Tropics (ICRISAT), Andhra Pradesh, India.

Wright, G.C., R.C. Nageswar-Rao and M.S. Basu. 1996. A physiological approach to the understanding of Genotype by environment interaction: A case study on improvement of drought Adaptation in Groundnut. In: Plant Adaptation and Crop Improvement, (Eds. Cooper, M. and G.L Hammer CAB International, Wallingford, UK., ISBN: 085199-108-4. 
Nepal Journal of Science and Technology Vol. 14, No. 1 (2013) 41-50 